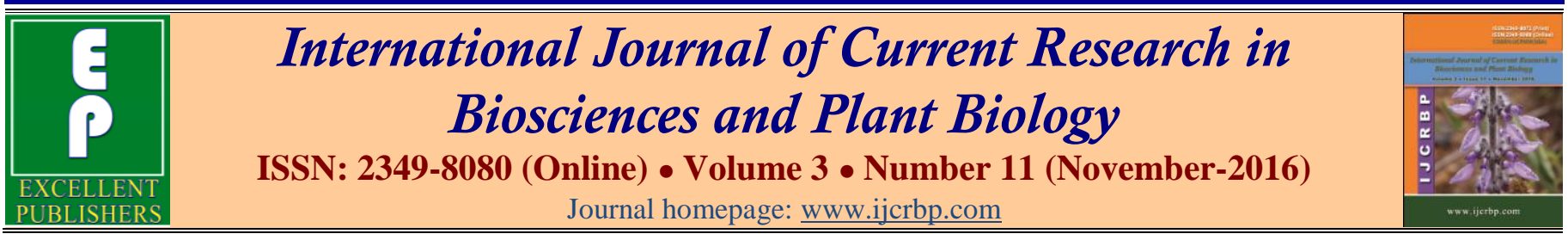

\title{
Elicitation of Flavonoids in Blumea lacera (Burm.f.) DC. Cell Culture using Chemical Elicitor, Salicylic Acid and Biological Elicitor, Aspergillus niger
}

\author{
Vijay D. Mendhulkar*, Priyanka Patade and Moinuddin Vakil
}

Department of Botany, The Institute of Science, 15, Madam Cama Road, Mumbai- 40o o32, Maharashtra, India

*Corresponding author.

\section{Abstract}

The present work was aimed to elicit flavonoid synthesis in cultured cells of Blumea lacera (Burm.f.) DC using Salicylic acid and Aspergillus niger as chemical and fungal elicitor respectively. Total flavonoid content in cultured cells was determined by Aluminum chloride colorimetric method. The $1.5 \mathrm{mM}$ salicylic acid treatment for 24 hrs duration was highly responsive to elicit the flavonoid content $(0.098 \mathrm{mg} / \mathrm{g})$ as maximum as 2.8 fold over control $(0.035 \mathrm{mg} / \mathrm{g})$. In case of biological elicitor, Aspergillus niger treatment with $1.5 \mathrm{ml}$ concentration for 4 days duration revealed 3.3 fold enhancement in flavonoid content $(0.036 \mathrm{mg} / \mathrm{g})$ as compared to control $(0.011$ $\mathrm{mg} / \mathrm{g}$ ). The results indicate that for flavonoid elicitation in Blumea lacera, Aspergillus niger is more responsive than Salicylic acid.

\section{Article Info}

Accepted: 30 October 2016

Available Online: 06 November 2016

\section{Keywords}

Aspergillus niger

Blumea lacera

Cell culture

Flavonoids

Salicylic acid

\section{Introduction}

Plants have been the source for many important drugs because they are able to produce various chemical entities and bioactive molecules through the process known as metabolism. Plant derived secondary metabolites have played an essential role as medicine for thousands of years. The plant as a source for important drug molecules is witnessed through the discoveries of various bioactive molecules such as taxol, vincristine, vinblastine, metformin, morphine, etc. Currently, secondary metabolites with bioactivity are being isolated and used either directly or after chemical modification. Their pharmacological value is increasing due to the constant discoveries of their potential roles in healthcare and as lead compounds for new drug development (Shilpa et al., 2010).

The active constituents of the plants are still obtained commercially by extraction from their whole plant sources. The natural compounds are often difficult to synthesize chemically due to their complexity in their chemical structure. However, Plant cell culture has become an alternative for producing bioactive compounds at large (Kolewe et al., 2008).

The qualitative and quantitative improvement of biologically active compounds by in-vitro techniques has been achieved most successfully and promisingly in many medicinal plants (Ramawat and Merillion, 1999). Enhancement in the production of secondary metabolites using chemical and biological elicitors is one of the few strategies recently finding commercial application. Elicitors are chemical compounds which trigger the increased production of secondary metabolites (Robins et al., 1986; Eilert et al., 1986; Sim et al., 1994). The elicitors can be biological or chemical in origin. The yeast elicitor, Saccharomyces cereviseae increased the production of berberine by 4 -folds in Thalictrum 
rugosum. Rajendran et al. (1994) observed 3-fold elicitation of anthocyanin by Aspergillus flavus mycelial extract in cultured cells of Daucus carota. Kang et al. (2006) studied the effect of the elicitor salicylic acid (SA) on the production of bilobalide, ginkgolide A (GA), and ginkgolide B (GB) in cell suspension cultures of Ginkgo biloba. Buitelaar et al. (1992) reported 85\% increase in thiophene production with Aspergillus niger elicitor whereas it was 55\% with Penicillium expansum elicitor in the hairy roots of Tagetes patula. Cell suspension cultures of Taxus chinensis, treated with 20, 40 and $100 \mathrm{mg} / \mathrm{L}$ Aspergillus niger elicitor showed 5, 8 and 3 -fold increase in taxol production than that of the control (Lan et al., 2003).

Blumea lacera (Burm.f.) DC. is a medicinal plant with strong odour of terpentine and it belongs to Asterceae family. In Ayurveda, Blumea lacera is described as anthelmintic, liver tonic, expectorant, thermogenic, antiinflammatory, ophthalmic, digestive, antipyretic and memory enhancer (Warrier et al., 1996). The plant is astringent, diuretic and useful in catarrhal affections (Quisumbing, 1998). Essential oil has analgesic, hypothermic, tranquillizing and antimicrobial activity (Dixit and Verma, 1976; Bharnagar et al., 1977).

Campestrol, triterpenoid and prenylated phenol glycosides are the main active constituents of $B$. lacera (Pal et al., 1972; Agarwal et al., 1995). The other important constituents are flavonoids (Rao et al., 1997), monoterpene glycoside (Ragasa et al., 2007). The essential oil of the plant include $\beta$-caryophyllene, thymol hydroquinone dimethyl ether, caryophyllene oxide, $\alpha$ humulene and E- $\beta$-farnesene (Laakso,1989) and coniferal alcohol derivative (Bohlmann and Zdero, 1969).

Owing to the medicinal properties of Blumea lacera and encouraging reports of elicitation, the present study conducted to enhance the synthesis of campesterol using Salicylic acid and Aspergillus niger as chemical and fungal elicitors in cultured cells of Blumea lacera.

\section{Materials and methods}

\section{Cell culture}

The leaves collected from Vasai fort, Maharashtra were used as explants for callus induction on MS medium supplemented with 2,4-D:BAP (1.0:0.5 mg/l). After obtaining fragile callus, $2 \mathrm{~g}$ of callus was inoculated into tissue culture bottle containing $50 \mathrm{ml}$ MS medium with same medium composition except agar. The cultures were placed on a shaker with $120 \mathrm{rpm}$ and at $25^{\circ} \mathrm{C}$ under complete darkness.

\section{Preparation of chemical elicitor-Salicylic acid}

$100 \mathrm{mg}$ of Salicylic acid was dissolved in $10 \mathrm{ml}$. The solution was autoclaved at $15 \mathrm{lbs}$ for $20 \mathrm{~min}$ before use. $0.05 \mathrm{mM}, 0.5 \mathrm{mM}$ and $1.5 \mathrm{mM}$ concentrations of Salicylic acid were added to cell suspension culture for 24, 48 and $72 \mathrm{hrs}$. The treatment was administered on day 21 of cell suspension culture and these cultures were incubated at $25 \pm 2^{\circ} \mathrm{C}$ in gyratory shaker $(120 \mathrm{rpm})$ under dark condition.

\section{Preparation of fungal elicitor-Aspergillus niger}

Aspergillus niger culture was obtained from Institute of Microbial technology, Chandigarh. Aspergillus niger cultures grown in $250 \mathrm{ml}$ flasks containing $100 \mathrm{ml}$ of Czapekdox broth were harvested after three weeks. The fungal cultures were autoclaved along with the media at 15 psi for 20 min. After autoclaving, the fungal mycelial mat was washed several times with distilled water and allowed to dry in hot air oven at $40^{\circ} \mathrm{C}$. The dried mycelium mat was powdered using mortar and pestle and used as DCP (Dry Cell Powder). $2 \mathrm{~g}$ of DCP was boiled in $200 \mathrm{ml}$ distilled water $(\mathrm{pH} 2)$ for $45 \mathrm{~min}$. After boiling the $\mathrm{pH}$ was adjusted to 5 with $1 \mathrm{~N} \mathrm{NaOH}$ and the volume was adjusted to $200 \mathrm{ml}$ with $\mathrm{D}$.W. This solution was autoclaved at $15 \mathrm{psi}$ for $20 \mathrm{~min}$. before use. $1 \mathrm{ml}, 1.5$ $\mathrm{ml}$ and $2 \mathrm{ml}$ of this fungal elicitor were added to $B$. lacera cell suspension culture separately. $1 \mathrm{ml}, 1.5 \mathrm{ml}$ and $2 \mathrm{ml}$ of concentration contained to $9.8 \mathrm{mg}, 14.7 \mathrm{mg}$ and $19.66 \mathrm{mg}$ of fungal polysaccharide $1-1$ respectively. The concentrations of total carbohydrate content in fungal homogenate were determined by the phenol-sulphuric acid assay using glucose as the standard. Each of the fungal concentrations was subjected for the treatment duration of 4 days, 7 days and 10 days. The treatment was administered on day 21 of cell suspension culture.

\section{Extraction and preparation of samples}

After the treatment of elicitors, the cells were filtered and washed several times with distilled water. The filtered cells were dried in oven at $40^{\circ} \mathrm{C}$ and powdered using mortar and pestle. $100 \mathrm{mg}$ of powdered sample was sonicated in $2 \mathrm{ml}$ methanol using $2 \mathrm{~mm}$ probe for $10 \mathrm{~min}$ with pulse rate operating at $10 \mathrm{sec}$ on and $2 \mathrm{sec}$ off, amplitude $20 \%$ using SONICS Vibra Cell (VCX 130) instrument. The extract was centrifuged at $5000 \mathrm{rpm}$ for $5 \mathrm{~min}$. the supernatant was transferred into $2 \mathrm{ml}$ vials. This extract was used for 
identification and quantification of flavonoids by TLC and UV-Vis spectrophotometer respectively.

\section{Detection and quantification of total flavonoid content}

Flavonoids in treated cultures were detected by High Performance Thin Layer Chromatography (HPTLC) and for quantification of total flavonoid content Aluminium Chloride Colorimetric method was using UV- Vis Spectrophotometer.

\section{High Performance Thin layer chromatography (HPTLC)}

For HPTLC, aluminium-backed precoated silica gel 60 F254 TLC plate $(0.2 \mathrm{~mm}$ thickness, E. Merck) was used. $10 \mu \mathrm{l}$ of sample was loaded as $8 \mathrm{~mm}$ wide bands by Linomat IV Camag (Switzerland) sample applicator fitted with a $100 \mu \mathrm{l}$ syringe (Hamilton, Bonaduz make, Switzerland). Ethyl acetate: formic acid: acetic acid: water (13.42:1.47:1.47:3.62) was used as mobile phase. After running the mobile phase, plates were heated for 10 minutes and sprayed with ethanolic Polyethylene glycol (4000 MW). The plate was screened under UV light with a wavelength of $365 \mathrm{~nm}$ (Males et al., 2006). Yellow coloured bands of flavonoids appeared on the TLC plate.

\section{Estimation of total flavonoids}

The total flavonoids content in treated samples was determined using the aluminum chloride colorimetric method (Chang et al., 2002). Quercetin (Sigma-Aldrich) was used as reference standard.

\section{Results}

Flavonoid were detected as yellow coloured bands on TLC plates after derivatization with $5 \%$ ethanolic Polyethylene Glycol (Fig.1). Quantification of total flavonoid content was done on UV- Vis spectrophotometer using Aluminium Chloride Colorimetric method. Standard quercetin was used as reference standard (Table 1; Fig. 2).

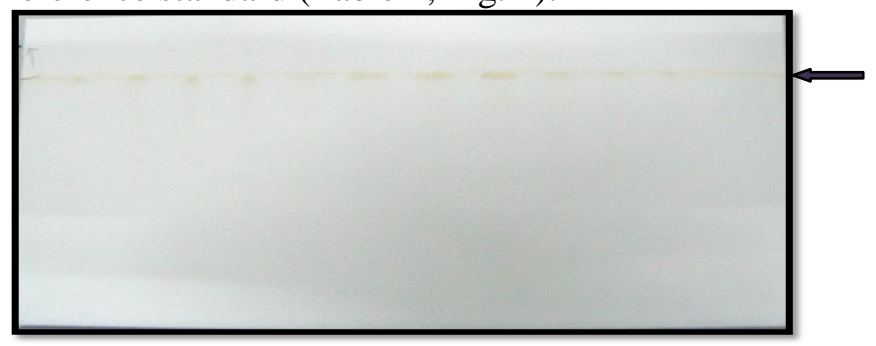

Fig. 1: HPTLC chromatogram showing flavonoids as yellow band (arrow mark).
Table 1. Absorbance reading against quercetin concentration.

\begin{tabular}{ll}
\hline Quercetin $(\boldsymbol{\mu g})$ & Optical density $($ at $\mathbf{4 1 5} \mathbf{~ n m})$ \\
\hline 12.5 & 0.0732 \\
25 & 0.1564 \\
50 & 0.2432 \\
75 & 0.3382 \\
100 & 0.4243 \\
125 & 0.5242 \\
\hline
\end{tabular}

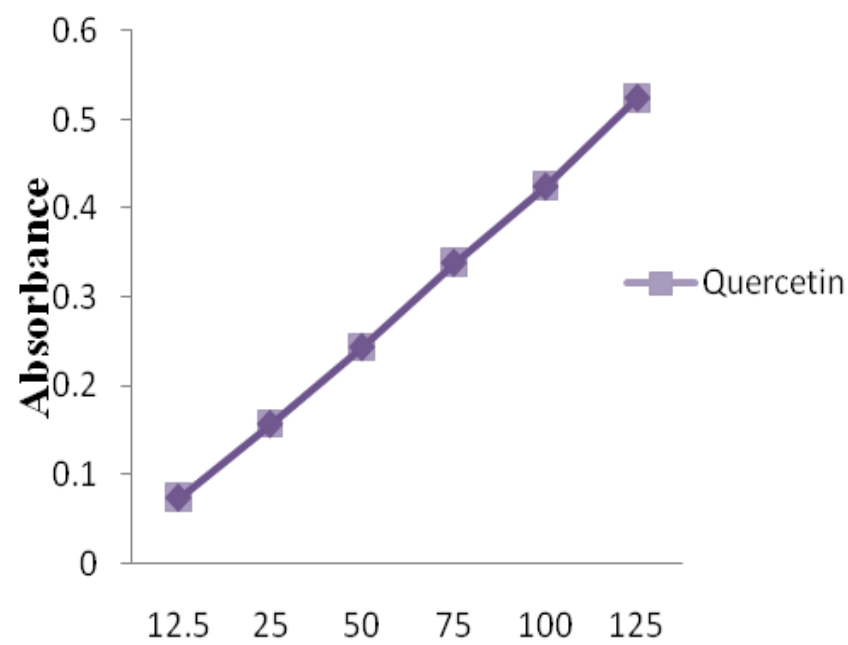

Fig. 2: Quercetin $(\mu \mathrm{g})$.

\section{Salicylic acid mediated elicitation for flavonoid} content

The studied concentrations of salicylic acid i.e. $0.05 \mathrm{mM}$, $0.5 \mathrm{mM}$ and $1.5 \mathrm{mM}$ for $24 \mathrm{hrs}$ treatment showed $0.054 \pm$ $0.013 \mathrm{mg} / \mathrm{g}, 0.093 \pm 0.008 \mathrm{mg} / \mathrm{g}$ and $0.098 \pm 0.011 \mathrm{mg} / \mathrm{g}$ of total flavonoid content respectively in context to $0.035 \pm 0.007 \mathrm{mg} / \mathrm{g}$ in control. Comparatively high amount of flavonoid content was observed in $1.5 \mathrm{mM} \mathrm{SA}$ treatment.

The treatment with $0.05 \mathrm{mM}$ and $1.5 \mathrm{mM}$ SA for $48 \mathrm{hrs}$ duration showed $0.063 \pm 0.009$ and $0.042 \pm 0.008 \mathrm{mg} / \mathrm{g}$ amount of flavonoid content which was slightly more to control $(0.033 \pm 0.015)$. Whereas, lowest quantity of content for $48 \mathrm{hrs}$ was observed in $0.5 \mathrm{mM}$ SA $(0.019 \pm$ $0.006 \mathrm{mg} / \mathrm{g}$ ). Higher amount of total flavonoid content $(0.063 \pm 0.009 \mathrm{mg} / \mathrm{g})$ was observed in $0.05 \mathrm{mM} \mathrm{SA}$.

Total flavonoid content was $0.028 \pm 0.012 \mathrm{mg} / \mathrm{g}$ in $0.05 \mathrm{mM}, 0.024 \pm 0.010 \mathrm{mg} / \mathrm{g}$ in $0.5 \mathrm{mM}$ and $0.025 \pm 0.014$ $\mathrm{mg} / \mathrm{g}$ in $1.5 \mathrm{mM} \mathrm{SA}$ concentrations for $72 \mathrm{hrs}$ treatment whereas in control it was $0.010 \pm 0.006 \mathrm{mg} / \mathrm{g}$. The lowest concentration of salicylic acid i.e. $0.05 \mathrm{mM}$ indicates comparatively high content of total flavonoid content in this treatment duration (Table 2; Fig.3). 
Table 2. Total flavonoid content in Blumea lacera cell suspension cultures treated with chemical elicitors.

\begin{tabular}{|c|c|c|c|}
\hline Elicitor & $\begin{array}{l}\text { Treatment } \\
\text { duration }\end{array}$ & Concentrations & $\begin{array}{l}\text { Total flavonoid } \\
\text { content }(\mathrm{mg} / \mathrm{g})\end{array}$ \\
\hline \multirow{12}{*}{ 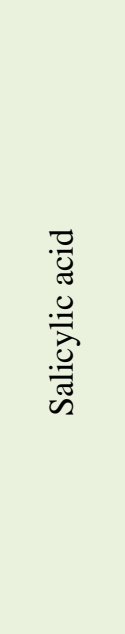 } & \multirow[t]{4}{*}{$24 \mathrm{hrs}$} & Control & $0.035 \pm 0.007$ \\
\hline & & $0.05 \mathrm{mM}$ & $0.054 \pm 0.013$ \\
\hline & & $0.50 \mathrm{mM}$ & $0.093 \pm 0.008$ \\
\hline & & $1.50 \mathrm{mM}$ & $0.098 \pm 0.011$ \\
\hline & \multirow[t]{4}{*}{$48 \mathrm{hrs}$} & Control & $0.033 \pm 0.015$ \\
\hline & & $0.05 \mathrm{mM}$ & $0.063 \pm 0.009$ \\
\hline & & $0.50 \mathrm{mM}$ & $0.019 \pm 0.006$ \\
\hline & & $1.50 \mathrm{mM}$ & $0.042 \pm 0.008$ \\
\hline & \multirow[t]{4}{*}{$72 \mathrm{hrs}$} & Control & $0.010 \pm 0.006$ \\
\hline & & $0.05 \mathrm{mM}$ & $0.028 \pm 0.012$ \\
\hline & & $0.50 \mathrm{mM}$ & $0.024 \pm 0.010$ \\
\hline & & $1.50 \mathrm{mM}$ & $0.025 \pm 0.014$ \\
\hline
\end{tabular}

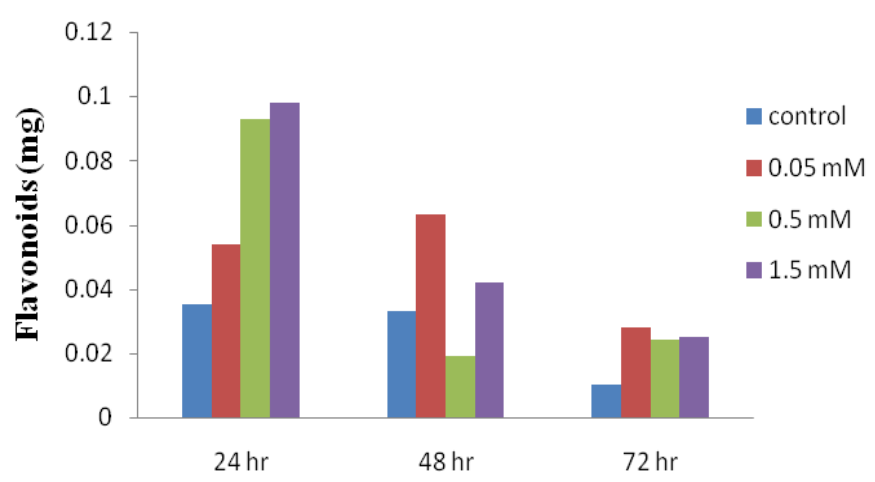

Fig. 3: Effect of salicylic acid on flavonoids synthesis in Blumea lacera cell culture.

The treatment duration has a great impact on induction of quantitative variation in the content of metabolites as equal to the concentration of elicitor. In the present experiment, $24 \mathrm{hrs}$ treatment showed good amount of total flavonoid content. The maximum fold enhancement in this treatment was 2.8 compared to control. $48 \mathrm{hrs}$ treatment duration showed 1.9 fold increase whereas it was again 2.8 fold in 72 hrs treatment duration with respect to control.

It was observed that for lowest treatment duration (24 hrs) the highest concentration of SA $(1.5 \mathrm{mM})$ and for highest treatment duration ( $72 \mathrm{hrs)}$ lowest concentration $(0.05 \mathrm{mM})$ was most favourable. Results obtained in present investigation indicated that, $1.5 \mathrm{mM}$ salicylic acid treatment for $24 \mathrm{hrs}$ duration was the best suitable treatment for the elicitation of total flavonoid content in Blumea lacera cell suspension culture. However, amount of total flavonoid content $(0.098 \pm 0.011 \mathrm{mg} / \mathrm{g})$ observed in this treatment was less than in vivo grown plant extract $(0.154 \pm 0.022 \mathrm{mg} / \mathrm{g})$.

\section{Aspergillus niger mediated elicitation for flavonoid content}

Aspergillus niger elicitor prepared from fungal mycelium was used in three different concentrations $(1 \mathrm{ml}, 1.5 \mathrm{ml}$ and $2 \mathrm{ml}$ ). Each concentration was subjected for 4 days, 7 days and 10 days treatment duration. $1 \mathrm{ml}, 1.5 \mathrm{ml}$ and 2 $\mathrm{ml}$ of Aspergillus niger elicitor for 4 days treatment duration showed $0.017 \pm 0.008,0.036 \pm 0.010$ and $0.031 \pm$ $0.007 \mathrm{mg} / \mathrm{g}$ flavonoid content, respectively. The control sample indicates $0.011 \pm 0.009 \mathrm{mg} / \mathrm{g}$ flavonoid content.

Highest quantity of flavonoids was recorded in $1.5 \mathrm{ml}$ concentration treatment. For 7 days treatment duration, $0.034 \pm 0.020$ and $0.029 \pm 0.017 \mathrm{mg} / \mathrm{g}$ of flavonoid content was observed in $1.5 \mathrm{ml}$ and $2 \mathrm{ml}$ concentration respectively compared to $0.024 \pm 0.012 \mathrm{mg} / \mathrm{g}$ in control. However the flavonoid quantity in $1 \mathrm{ml}$ concentration treatment $(0.013 \pm 0.008 \mathrm{mg} / \mathrm{g})$ indicates low estimate compared to control. Total flavonoid content in all the three studied concentration for 10 days was $0.017 \pm$ $0.012,0.046 \pm 0.008$ and $0.050 \pm 0.012 \mathrm{mg} / \mathrm{g}$ respectively. Total flavonoid content in control for this treatment $(10$ days) was $0.021 \pm 0.015 \mathrm{mg} / \mathrm{g}$. The $1 \mathrm{ml}$ concentration treatment repeats its status of low estimate for flavonoid content compared to control similar to 7 days treatment (Table 3; Fig. 4).

Table 3. Total flavonoid content in Blumea lacera cell suspension cultures treated with fungal elicitors.

\begin{tabular}{|c|c|c|c|}
\hline Elicitors & $\begin{array}{l}\text { Treatment } \\
\text { duration }\end{array}$ & Concentrations & $\begin{array}{l}\text { Total flavonoid } \\
\text { content (mg/g) }\end{array}$ \\
\hline \multirow{12}{*}{ 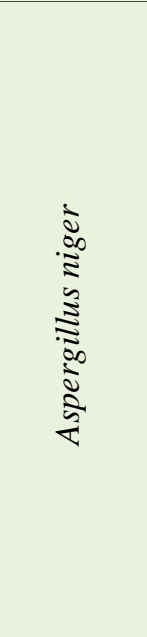 } & \multirow[t]{4}{*}{4 days } & Control & $0.011 \pm 0.009$ \\
\hline & & $1 \mathrm{ml}$ & $0.017 \pm 0.008$ \\
\hline & & $1.5 \mathrm{ml}$ & $0.036 \pm 0.010$ \\
\hline & & $2 \mathrm{ml}$ & $0.031 \pm 0.007$ \\
\hline & \multirow[t]{4}{*}{7 days } & Control & $0.024 \pm 0.012$ \\
\hline & & $1 \mathrm{ml}$ & $0.013 \pm 0.008$ \\
\hline & & $1.5 \mathrm{ml}$ & $0.034 \pm 0.020$ \\
\hline & & $2 \mathrm{ml}$ & $0.029 \pm 0.017$ \\
\hline & \multirow[t]{4}{*}{10 days } & Control & $0.021 \pm 0.015$ \\
\hline & & $1 \mathrm{ml}$ & $0.017 \pm 0.012$ \\
\hline & & $1.5 \mathrm{ml}$ & $0.046 \pm 0.008$ \\
\hline & & $2 \mathrm{ml}$ & $0.050 \pm 0.012$ \\
\hline
\end{tabular}




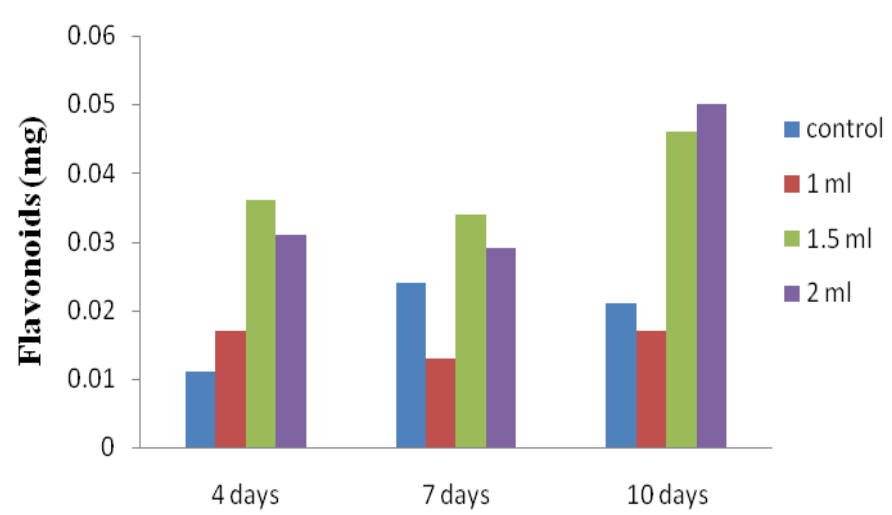

Fig. 4: Effect of Aspergillus niger elicitor on flavonoids synthesis in Blumea lacera cell culture.

The treatment duration used for the administration of elicitation with biological agents were of long hour compared to that of chemical agents. The interaction of eliciting causal factor of biological origin with synthesis pathway of metabolites might require adequately more period. However, it effectively elicits the metabolite content and it is justified by the published reports and by the results obtained in the present work. The treatment duration of 4 days indicate 3.3 fold improvement (for 1.5 $\mathrm{ml}$ concentration), 7 days treatment shows 1.4 fold (for $1.5 \mathrm{ml}$ concentration) and 10 days treatment revealed 2.4 fold (for $2 \mathrm{ml}$ concentration) enhancement in flavonoid estimate. Results obtained indicates moderate duration treatment (i.e. 4 days treatment) with $1.5 \mathrm{ml}$ concentration of Aspergillus niger elicitor dose as a most favored treatment that yields 3.3 fold in the content of flavonoid over control.

\section{Discussion}

Salicylic acid and Aspergillus niger elicitor have been reported to enhance the synthesis of metabolic compounds by many workers. Salicylic acid induces gene expression related to biosynthesis of secondary metabolites in plants (Taguchi et al., 2001). Pitta-Alvarez et al. (2000) treated hairy root cultures of Brugmansia candida with $0.01 \mathrm{mM}, 0.10$, and $1.00 \mathrm{mM}$ salicylic acid for 24,48 , and $72 \mathrm{hrs}$ to produce the tropane alkaloids scopolamine and hyoscyamine. Accumulation of both alkaloids in the roots was enhanced after $24 \mathrm{hrs}$, particularly with the highest and lowest concentrations of Salicylic acid. Salicylic acid $(0.05 \mathrm{mM})$ with $24 \mathrm{hrs}$ treatment duration showed 1.39 fold increment in total flavonoid content $(1.72 \mathrm{mg} / \mathrm{g})$ and 18.5 fold increment in andrographolide content $(37.0 \mu \mathrm{g} / \mathrm{g})$ in cultured cells of Andrographis paniculata (Mendhulkar and Vakil, 2013a; Vakil and Mendhulkar, 2013a). The findings of the present work are in accordance with the elicitation in Ginkgo biloba. The higher concentration of salicylic acid affects cell growth. In an attempt to increase productivity, Kang et al. (2006) studied the effect of the elicitor salicylic acid (SA) on the production of bilobalide, ginkgolide A (GA) and ginkgolide B (GB) in cell suspension cultures of Ginkgo biloba. When the cultures were treated with $1.0 \mathrm{mM}$ Salicylic acid, cell growth decreased to $38 \%$ of the control culture growth after $48 \mathrm{hrs}$ of exposure. Treatment with exogenous SA also increased the production of bilobalide, GA, and GB and the release of these metabolites into the culture medium. Treatment with $0.1 \mathrm{mM}$ SA increased not only bilobalide content, but also GA and GB content. Baldi and Dixit, (2008) reported that acetyl salicylic acid (30 $\mathrm{mg} / \mathrm{L}$ ) significantly improved artemisinin production in cell cultures of Artemisia annua by 2.81 folds more over control. When hairy root cultures of Azadirachta indica were treated with $100 \mathrm{mM}$ of salicylic acid, there was about 9-fold increase in azadirachtin production over the control cultures (Satdive et al., 2007).

The published reports illustrates that Aspergillus niger effectively elicit the metabolite content in various systems. In Andrographis paniculata cell culture, $2 \mathrm{ml}$ of Aspergillus niger elicitor induced 1.39 fold enhancement in flavonoid content $(3.37 \mathrm{mg} / \mathrm{g})$ over the control $(2.42$ $\mathrm{mg} / \mathrm{g}$ ) when exposed for 4 days treatment duration. For andrographolide elicitation, $1.5 \mathrm{ml}$ of $A$. niger extract for 10 days treatment duration showed 6.94 fold increase in andrographolide content $(132 \mu \mathrm{g})$ over control (Mendhulkar and Vakil, 2013b; Vakil and Mendhulkar, 2013b). Ibrahim et al., (2007) added $2 \mathrm{ml}$ of Aspergillus niger dry cell powder solutions with the concentration of $10 \mathrm{~g} / \mathrm{l}$ in the suspension cultures of Nerium oleander after different culturing periods of 4, 8, 12, 20, 25 and 30 days old cultures. The oleandrin yield reached a maximum of $3.164 \mathrm{mg} / \mathrm{l}$ in 25-days upon employing Aspergillus niger elicitors. It was 8.8 -fold higher than that of control cultures which reached a maximum of $0.35 \mathrm{mg} / \mathrm{l}$. Various doses of Aspergillus niger 0.5, 1, 1.5 and $2 \%(\mathrm{v} / \mathrm{v})$ were added to the cell suspension cultures of Plumbago rosea to study the effect on plumbagin production (Komaraiah et al., 2002). Elicitors were added to 16-day-old cultures and harvested after $48 \mathrm{~h}$ of incubation. Maximum accumulation of plumbagin (16.56 $\mathrm{mg} / \mathrm{g} \mathrm{DCW}$ ) was observed with $1.5 \%$ (v/v) elicitor dose which showed almost four-fold increase over control cells $(4.31 \mathrm{mg} / \mathrm{g}$ DCW $)$. Chakraborty and Chattopadhyay, (2008) studied the impact of Aspergillus niger on the stimulation of menthol production in the cell suspension culture of Mentha piperita. Autoclaved 
fungal crude extract of Aspergillus niger was added to the culture on the day 1 at the concentration of 50-150 $\mathrm{mg} / \mathrm{l}$ and the culture was maintained for another 14 days. Addition of $100 \mathrm{mg} \mathrm{1-1}$ fungal extract showed the optimum activity in terms of biomass and menthol production, yielding $20.4 \mathrm{~g} / \mathrm{l}$ biomass and $140.8 \mathrm{mg} / \mathrm{l}$ menthol, respectively. Cell suspension cultures of Taxus chinensis, treated with 20, 40 and $100 \mathrm{mg} / \mathrm{l}$ Aspergillus niger elicitor showed 5, 8 and 3-fold increase in taxol production than that of the control (Lan et al., 2003).

\section{Conclusion}

The conducted research work reveals that highest concentration of salicylic acid $(1.5 \mathrm{mM})$ with lowest treatment duration $(24 \mathrm{hrs})$ and lowest concentration $(0.05 \mathrm{mM})$ with highest treatment duration (72 hrs) was most favourable for elicitation of flavonoid. The $1.5 \mathrm{mM}$ salicylic acid treatment for $24 \mathrm{hrs}$ duration was highly responsive to elicit the flavonoid content as maximum as 2.8 fold over control. In case of biological elicitor, Aspergillus niger treatment with $1.5 \mathrm{ml}$ concentration for 4 days duration revealed as maximum as 3.3 fold enhancement in flavonoid content. In present study, the elicitation of flavonoids may be attributed to the specificity of concentration, type of elicitor and treatment duration.

\section{Conflict of interest statement}

Authors declare that they have no conflict of interest.

\section{Acknowledgement}

The authors are thankful to the Director, The Institute of Science, Mumbai for providing the analytical facilities.

\section{References}

Agarwal, R., Singh, R., Siddiqui, I.R., Singh, J., 1995. Triterpenoid and prenylated phenol glycosides from Blumea lacera. Phytochemistry. 38, 935-938.

Baldi, A., Dixit, V.K., 2008. Enhanced artemisin in production by cell cultures of Artemisia annua. Curr. Trends Biotechnol. Pharm. 2(2), 341-348.

Bharnagar, S., Dixit, V.K., Nigam, S.S., Verma, K.C., 1977. Antimicrobial activity of essential oils of leaves of Blumea lacera D.C. and Blumea lanciniata D.C. Indian J. Hosp. Pharm. XIV(L), 14-16.

Bohlmann, F., Zdero, C., 1969. On a new coniferyl alcohol derivative from Blumea lacera D. Tetrahed. Lett. 2, 69-70.

Buitelaar, R.M., Cesário, M.T., Tramper, J., 1992. Elicitation of thiophene production by hairy roots of Tagetes patula.
Enz. Microb. Technol. 14, 2-7.

Chakraborty, A., Chattopadhyay, S., 2008. Stimulation of menthol production in Mentha piperita cell culture. In Vitro Cell. Dev. Biol. -Plant. 44, 518-524.

Chang, C.C., Yang, M.H., Wen, H.M., Chern, J.C., 2002. Estimation of total flavonoid content in propolis by two complementary colorimetric methods. J. Food Drug Anal. 10(3), 178-182.

Dixit, V.K., Verma, K.C., 1976. Effect of essential oil of leaves of Blumea lacera DC on central nervous system. Ind. J. Pharmac. 8(1), 7-11.

Eilert, U., Constabel, F., Kurz, W.G.W., 1986. Elicitorstimulation of monoterpene indole alkaloid, in suspension cultures of Catheranthus roseus. J. Plant Physiol. 126, 1122.

Ibrahim, A.K., Khalifa, S., Khafagi, I., Youssef, D., Khan, I., Mesbah, M., 2007. Stimulation of oleandrin production by combined Agrobacterium tumefaciens mediated transformation and fungal elicitation in Nerium oleander cell cultures. Enz. Microb. Technol. 41, 331-336.

Kang, S.M., Min, J.Y., Kim, Y.D., Kang, Y.M., Park, D.J., Jung, H.N., Kim, E.W., Choi, M. S., 2006. Effects of methyl jasmonate and salicylic acid on the production of bilobalide and ginkgolides in cell cultures of Ginkgo biloba. In Vitro Cell. Dev. Biol. -Plant. 42, 44-49.

Kolewe, M.E., Gaurav, V., Roberts, S.C., 2008. Pharmaceutically active natural product synthesis and supply via plant cell culture technology. Mol. Pharm. 5(2), 243-256.

Komaraiah, P., Amrutha, R.N., Kishor, P.B.K., Ramakrishna, S.V., 2002. Elicitor enhanced production of plumbagin in suspension cultures of Plumbago rosea L. Enz. Microb. Technol. 31(5), 634-639.

Laakso, I., Seppanen-Laakso, T., Hiltunen, R., Ekundayo, O., 1989. Composition of the essential oil of Blumea lacera DC. Asteraceae leaves from Nigeria. Flav. Fragr. J. 4, 73-76.

Lan, W.Z., Yu1, L.J.,. Li1, M.Y., Qin, W.M., 2003. Cell death unlikely contributes to Taxol production in fungal elicitorinduced cell suspension cultures of Taxus chinensis W. Biotechnol. Lett. 25, 47-49.

Males, Z., Plazibat, M., Vundac, V.B., Zuntar, I., 2006. Qualitative and quantitative analysis of flavonoids of the strawberry tree - Arbutus unedo L. (Ericaceae). Acta Pharm. 56, 245-250.

Mendhulkar, V.D., Vakil, M.M.A., 2013a. Elicitation of flavonoids by salicylic acid and Penicillium expansum in Andrographis paniculata (Burm.f.) Nees. cell culture. Res. Biotech. 4(2), 1-9.

Mendhulkar, V.D., Vakil, M.M.A., 2013b. Chitosan and Aspergillus niger mediated elicitation of total flavonoids in suspension culture of Andrographis paniculata (Burm.f.) Nees. Int. J. Pharm. BioSci. 4(4), (B), 731-740.

Pal, R., Moitra, S.K., Chakravarti, N.N., Adhya, R.N., 1972. Campesterol from Blumea lacera DC. Phytochem. 11, 1855.

Pitta-Alvarez, S.I., Spollansky T.C., Giulietti, A.M., 2000. The influence of different biotic and abiotic elicitors on the 
production and profile of tropane alkaloids in hairy root cultures of Brugmansia candida. Enz. Microb. Technol. 26(2-4), 252-258.

Quisumbing, E., 1998. Medicinal Plants of the Philippines, Katha Publishing Co. pp.966-967.

Ragasa, C.Y., Wong, J., Rideout, J.A., 2007. Monoterpene glycoside and flavonoids from Blumea lacera. J. Natural Med. 61(4), 474-475.

Rajendran, L., Suvarnalatha, G., Ravishankar, G.A., Venkataraman, L.V., 1994. Enhancement of anthocyanin production in callus cultures of Daucus carota L. under influence of fungal elicitors. Appl. Microbiol. Biotechnol. 42, 227-231.

Ramawat, K.G., Merillon, J.M., 1999. Biotechnology: Secondary Metabolites. Oxford \& IBH, New Delhi. 199p.

Rao, C.B., Rao, T.N., Muralikrishna, B., 1997. Flavonoids from Blumea lacera. Planta Med. 31, 235-237.

Robins, R.J., Robins, R.J., Payne, J., Rhodes, M.J.C., 1986. The stimulation of anthraquinones by Cinchona ledgeriana cultures with polymeric adsorbants. Appl. Microbial. Biotechnol. 24, 35-41.

Satdive, R.K., Fulzele, D.P., Eapen, S., 2007. Enhanced production of azadirachtin by hairy root cultures of Azadirachta indica A. Juss by elicitation and media optimization. J. Biotechnol. 128(2), 281-289.

Shilpa, K., Varun, K., Lakshmi, B.S., 2010. An alternate method of natural drug production: Eliciting secondary metabolite production using plant cell culture. J. Plant Sci. 5, 222-247.

Sim, S.J., Chang, H.N., Liu, J.R., Jung, K.H., 1994. Production and secretion of indole alkaloids in hairy root cultures of Catheranthus roseus: effects of in situ adsorption, fungal elicitation and permeabilization. J. Ferment. Bioeng. 3, 229-234.

Taguchi, G., Yazawa, T., Hayashida, N., Okazaki, M., 2001. Molecular cloning and heterologous expression of novel glucosyl transferases from tobacco cultured cells that have broad substrate specificity and are induced by salicylic acid and auxin. Eur. J. Biochem. 268, 4086-4094.

Vakil, M.M.A., Mendhulkar, V.D., 2013a. Salicylic acid and chitosan mediated abiotic stress in cell suspension culture of Andrographis paniculata (Burm.f.) Nees. for andrographolide synthesis. Int. J. Pharm. Sci. Res. 4(9), 3453-3459.

Vakil, M.M.A., Mendhulkar, V.D., 2013b. Enhanced synthesis of andrographolide by Aspergillus niger and Penicillium expansum elicitors in cell suspension culture of Andrographis paniculata (Burm. f.) Nees. Botanical Studies. 54, 49.

Warrier, P.K., Nambiar, V.P.K., Ramankutty, C., 1996. Indian Medicinal Plants. Arya Vaidya Sala, Kottakkal. Orient Longman Press. pp.135-138.

\section{How to cite this article:}

Mendhulkar, V. D., Patade, P., Vakil, M., 2016. Elicitation of flavonoids in Blumea lacera (Burm.f.) DC. cell culture using chemical elicitor, salicylic acid and biological elicitor, Aspergillus niger. Int. J. Curr. Res. Biosci. Plant Biol. 3(11), 85-91. doi: http://dx.doi.org/10.20546/ijcrbp.2016.311.013 